\title{
祥瑞型傾ける錯視と知覚の体制化
}

一図と地における背景の新たな役割一

菅野理樹夫

(高千穂大学 人間科学部)

キーワード: 図と地 背景 新錯視

\section{A new role of background on perceptual organization and slant illusion \\ Likio Sugano}

(Takachiho University, Human Science)

Key words: visual organization, background, new illusion

はじめに：「ものはなぜそのように見えるか」という問 いに対して, これまで知覚の体制化の観点からいくつか研究 がされてきた。近年ではJ. J. Gibsonのように環境世界と視覚 世界の合致 (Veridical Perception) あるいは直接知覚という 観点からも研究されている。その中で彼はものの知覚には背 景の役割が重要であると述べている (1979)。また, G. Kanizsa (1979)，S. Morinaga (1953) も同様の指摘をしている。本研 究は図と地の成り立ちに関する視覚の体制化について新しい 錯視（傾ける錯視）を供覧し困の出現には地である背景の連 続性や類似性などが重要な役割を示す新しい知見を述べる。

本研究に用いた新錯視は「傾ける錯視」と呼ばれる。それ は 6 つ横に並んだ各正方形の内側に大きさの小さい正方形を 順に2種類描いたものである。さらに各正方形に対角線上で交 差する直線を引くと, 正面からの知覚は横に並んだピラミッ ドを真上から見たときのようである。しかし，この図形を傾 けて眼の高さの位置で横方向から観察するとそこにはあるは ずがない一連の連続した直線群が現れ，その上に 5 つの連な った菱形（内部が縦縞になっている）が突然浮き出る。この ことは連続した直線群が地（背景）として出現したときに図 (菱形) の知覚を確かなものしている重要な事実である。

背景の役割：J.J.Gibsonn は「The Perception of the Visual world (1950)」の中で視覚世界に関する新たな理論として，「連続 的な背景面の知覚なしには，文字通り空間知覚と呼べるもの は何もないという可能性」を考えていた。さらに彼はその著

「The Ecological Approach to Visual Perception(1979)」の中で, 「視覚世界の特徵は, 対象によってではなく, 対象の背景に よって与えられる。と述べている。同様に G. Kanizsa もそ の著「Organization in Vision : Essays on Gestalt Perception(1979)」 の中で「図一地の分化において, 分節は図の背後に存在する 連続的な地の完結化（正確には非感性的完結化）を必然的に 伴う」と指摘している。さらに，「現象的に図として見えるす べての対象は, 図の背後に非感性的に存在する背景の手前に あるように見えるだけでなく，(中略），この背後の部分は， 見えないけれども, 現象的には存在する。」と述べている。ま た，カニツッアは「異種輪郭である三角形の成立のためには 背景にある隠れたものの存在が必要である」と指摘している。

盛永（1953）は「類同の法則と視野体制」の中で,「図と地 の成立は視野内の類同性の破れ（異なる類同性の成立）によ って生じる」と述べ, Wertheimer は類同の法則を図のまとま りのみに言及していること指摘し，地の成り立ちについても このことがあてはまるか否について実験的観察を行っている。 これらの観察事例から, 地の見え方の基本も類同の法則にし たがっていることを示し, 図の背後に拡がり, 切れ切れにな らないで一体性をなす連続的な類似性は地を形成せるための 良い観察条件であると述べている。本研究はこれらの知見か ら，地である背景，すなわち変化の連続体あるいはその類似 した構造が図の形成あるいは視覚の体制化に重要な役割を担
っていることを示すために新たに発見した「傾ける錯視」現 象を用いて考察を行う。

現象観察: 観察図形は横に 6 つ並んだ正方形があり, その内 側に大きさの小さい正方形を順に 2 種類描かれている。さら に各正方形の対角線上から交差した直線を 2 本引くと, 正面 からはピラミッドを真上から見たときのように見える (図 1)。 しかし，この図形を傾けて横方向から眼の高さで観察すると そこにはあるはずがない一連のつながりを持った 6 本の直線 群が現れ，同時にその上に $5 つ の$ 連なった菱形（内部は縦縞 模様である）が突然知覚される（図 2）。この図形の由来は 中国明時代末に日本からの注文より景徳鎮で作られた茶器の 染付磁器に用いられた祥瑞(しょんずい)の図柄の一部である。 考察: 本研究で用いた図形を正面から観察する条件での知覚 はピラミッドを真上から見ている形と菱形の図形が共存し, 図と地の安定しない知覚事態である (図 1)。しかし, この図 形を側方から眼の位置で観察すると連続した 6 本の直線群が 地（背景）として出現すると同時に，その上に 5 つのひし形 が図としてあらわれる（図 2)。このことは類同性の破れがも のの知覚を確かなものしている重要な事実である。その要因 として地の連続性や類似性などが図のみならず, ものの知覚 を支える大きな役割を担っている。

文献 :

1. J.J.Gibsonn (1979) The Ecological Approach to Visual Perception Boston: Houghton Mfflin

2. G.Kanizsa (1979) Organization in Vision : Essays on Gestalt Perception Praeger Publishers

3. 盛永四郎（1953）類同の法則と視野体制，235-241, 知覚心理学 (明玄書房 $/ 1969$ に収録)

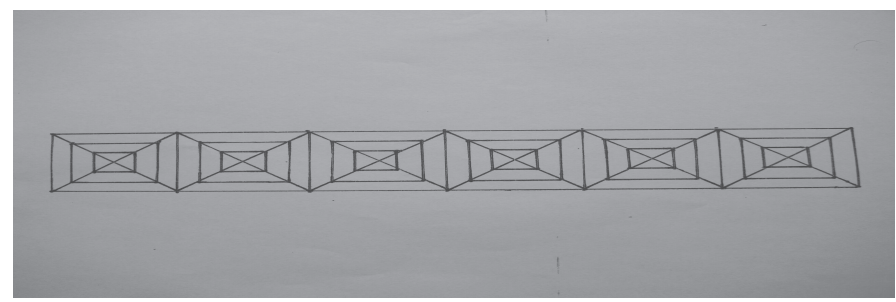

図 1 正面からの観察図形

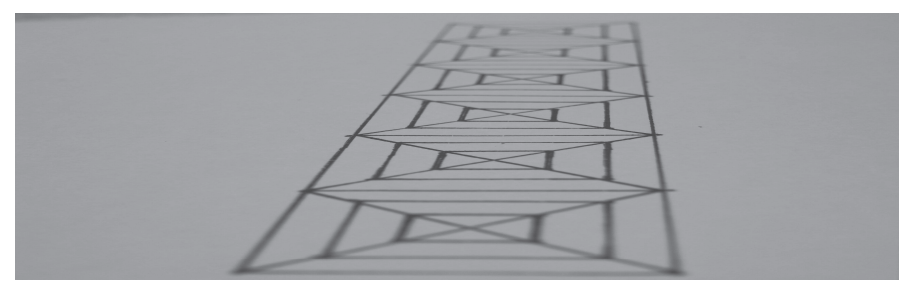

図 2 水平方向から観察した図形（横方向からの観察）

(Likio SUGANO) 